\title{
Composição, improviso e variação. A escrita dos Recados de Ifá.
}

\author{
Olavo de Souza Pinto Filho \\ Doutorando em Antropologia Social PPGAS-USP
}

Este artigo $^{1}$ tem como tema central a composição dos versos de Ifá escritos pelo Alapini Paulo Braz Ifamuiyde. Paulo Braz Felipe da Costa, é neto do famoso babalorixá recifense Felippe Sabino da Costa, mais conhecido como Pai Adão. Ele dirige, em conjunto com sua irmã; Maria Lúcia Felipe da Costa, o terreiro Ilè Iyemoja Ogunte, fundado em meados da década de 1970, onde zelam pelos orixás da família. O terreiro é uma dissidência do Ilê Oba Ogunte², mais conhecido como "Sítio de Pai Adão". Ambos estão localizados em Água-Fria, zona norte da cidade do Recife. Em 1997, Pai Paulo teve um infarto seguido de um acidente vascular cerebral (AVC). Seu médico lhe disse que, para ajudar em sua recuperação, era preciso ler e fazer anotações em voz alta. Um amigo, então, lhe deu um livro sobre Ifá, no qual ele lia os odus, anotando-os em um caderno. Segundo ele, "essas coisas eu já sabia, eu já tinha isso, mas quando eu li o livro, essas coisas se encaixaram, foi com isso que me curei". Essa cura, por intermédio do aprendizado do jogo de Ifá, deu-lhe um novo nome, "Ifatóògún", que significa: Ifá é meu remédio. "Fui curado por Ifá".

Ifá é um sistema oracular de origem iorubana, que é baseado no manejo de dezesseis caroços de dendê, para obter uma combinação entre um conjunto de 256 signos gráficos denominados odus (destinos), cada odu contém uma quantidade de versos ou recados que compõem seus significados.

Minha incursão etnográfica atenta-se sobre os modos como Pai Paulo convencionaliza sua experiência com Ifá a partir da escrita em seus cadernos dos "recados de Ifá", O que Pai Paulo nos ensina sobre Ifá é que o jogo, apesar de obedecer uma combinação entre as caídas dos odus e os seus significados, também incorpora, em seu corpus, a própria experiência de quem o executa. O conhecimento sobre os odus é, antes de tudo, uma experimentação. Isso impele a cada pessoa, ao aprender o manejo dos odus, compor, com sua própria experiência, os enunciados de Ifá.

\section{Ifatóògun: Fui curado por Ifá}

\footnotetext{
${ }^{1}$ Parte desse artigo integra minha dissertação de mestrado "Cadernos Nagô. A antropologia reversa do Alapini Paulo Braz Ifamuiyde" defendida em fevereiro de 2013 na Universidade de S

${ }^{2}$ Os termos em itálico referem-se a conceitos e palavras "nativas" bem como termos estrangeiros. Aspas simples para conceitos teóricos e aspas duplas para citação de meus interlocutores.
} 
Pai Paulo acorda às cinco da manhã. Levanta sentindo a cabeça meio fraca e sente uma agonia subindo das costas para o pescoço. "Deve ser a diabetes", ou algum efeito da trombose que, às vezes, manifesta-se. Da janela de seu quarto, a luz do sol reflete sobre sua cama, diretamente. Aos pés da janela, uma antiga bicicleta ergométrica. Ele sobe na bicicleta e começa a pedalar. Antigamente, podia caminhar pela avenida beira mar, que se encontra a uns 300 metros de seu quarto. Mas com os pés inchados, piorando a cada dia, o jeito é exercitar-se na bicicleta. Enquanto suas pernas movimentam os pedais, ele começa a saudar Ifá. “Ifá mojuba ...”. Sente a tontura novamente tomar sua cabeça e encerra o exercício. Seu estômago está vazio.

Ele levanta, dá dois passos e abre uma esteira no chão, que estava dobrada. No centro da esteira, uma pequena tábua redonda de madeira, o opom. Resquícios de um pó amarelo assenta-se em suas extremidades e marca os entalhes de sua borda. Pai Paulo retira uma pequena almofada, que cobre sua superfície, e coloca-a de lado. Perfilados ao lado do opom, há uma linha de ikins - os caroços negros de dendê, "por onde fala Ifá". Pai Paulo os coloca perto da boca e continua sua invocação. Abre uma pequena sacola branca de pano, retira um recipiente de plástico, contendo um pó amarelo em seu interior. Com os dedos, pega uma quantidade e coloca na boca, em seguida, salpica um pouco desse pó nos instrumentos ao lado do opom, uma casca de caracol quebrada, um pedaço de osso, dois búzios unidos por uma cera escura (chamados igualmente de ikin). Terminado esse processo, ele espalha, na superfície de madeira, o pó, até que ele cubra totalmente o espaço delimitado por um círculo concêntrico. Sua mão direta traça uma reta da extremidade superior à inferior. Pega os 16 ikins e os manipula, batendo uma mão na outra. Alguns escapam e ele traça uma pequena marca vertical ao lado direto. Repete o movimento com as mãos e novamente os ikins caem. Ele agora traça uma marca ao lado esquerdo. Ao terminar esse processo, ele olha o desenho dos traços da madeira e anota em um caderno espiral o odu que Ifá determinou naquele dia.

Levanta-se da esteira e segue para a cozinha do apartamento. Suas filhas, provavelmente, estão dormindo ainda. Abre a geladeira e pega uma jarra de chá, "camomila com dois mastruzes batidos. Isso diminui a diabetes". Bebe o chá e come um pão. Vai ao banheiro e toma seu banho. Volta ao quarto para continuar o jogo. É preciso saber sobre o que fala esse odu, qual seu recado para o dia de hoje. Quase embaixo do opom, está uma corrente de ferro com oito partes incrustadas ao longo de sua extensão. É o opelê, “auxiliar do opom”, diz Pai Paulo. Ele pega a corrente ao meio, com sua mão direita, e a levanta. As duas pontas que se formam tendem ao chão. Com elas, ele toca cada instrumento que consulta Ifá. Ao terminar esse rápido cumprimento, atira o opelê na esteira. Ele 
repete esses movimentos mais algumas vezes, em cada lance, ele anota outra configuração de odus em seu caderno. Agora ele pensará no recado do jogo e escreverá em seu sítio na internet. Está pronto para começar o dia.

Em 6 de fevereiro de 1997, Pai Paulo teve um infarto e foi levado às pressas a um hospital particular. No dia 7 de Março do mesmo ano, ele foi internado para o procedimento de cateterismo. Por negligência ou erro médico, não foram feitos os exames preventivos ao uso do contraste, houve, por isso, uma reação alérgica à substância que desencadeou, em Pai Paulo, uma nova parada cardíaca e uma trombose do lado esquerdo do cérebro. Pai Paulo ficou na UTI por 8 dias. Um segundo erro médico agravou o quadro clinico: como paciente que sofre de diabetes, foi-lhe ministrado um soro com glicose, que quase o matou.

"Eu tive um infarto em 1997 e depois uma trombose, porque eu era alérgico ao contraste do cateterismo me deu uma trombose do lado esquerdo do cérebro, ele falava: Seu Paulo, o senhor está sentindo alguma coisa? E eu falava que nada, porque ia perdendo o movimento do corpo quando o líquido subia nas minhas veias. Aí eu fique de cama, sem me mexer ou falar. Me dando dor de cabeça e no estomago, porque me deram dipirona, sou alérgico também, aí não sabia se estava vivo ou se estava morto"

A recuperação foi lenta. Um dos efeitos do AVC foi a perda parcial dos movimentos do lado direito do corpo, bem como impossibilidade de fala e problemas com a memória. Diante de tal quadro, o médico de Pai Paulo sugeriu, como exercício de recuperação, a leitura em voz alta e a prática da escrita. Seus interesses literários eram os livros que falavam sobre o candomblé. Já tinha lido os Nagô e a Morte de Juana Elbein dos Santos, e tinha gostado de ver transcrito, ali, inúmeras rezas e invocações em iorubá, e sua tradução para o português. Um amigo tinha comprado um livro e oferecido a Ajibola (nigeriano amigo de Pai Paulo), que declinando do presente recomendou que presenteasse Pai Paulo, e assim sucedeu.

Pai Paulo seguiu com as recomendações médicas, lia o livro sobre Ifá e falava em voz alta o conteúdo do livro (no começo, como a fala estava afetada pelo AVC, não conseguia se fazer entender). Na medida em que avançava nas leituras, comparava o que estava descrito no livro com seus próprios conhecimentos sobre Ifá. Pai Paulo me conta que Ifá veio de família, "herança familiar", que seu avô Adão "era de Ifá", mas que não praticava como babalaô, porque tinha um Exu que trabalhava com pimenta, o que era "tabu" de Ifá. De toda forma, Pai Adão consultava o jogo com frequência.

"Meu Avô [Adão] jogava os ikins, marcava o odu no opom, mas seus filhos não pegaram isso. Meu pai sempre contava como meu avô cantava as toadas de Ifá, as invocações, e como ele fazia com as 
mãos [faz o gesto] e marcava os odus. Ele aprendeu isso na senzala, junto com os negros. Então, meu pai lembrava, e eu fiquei com isso na cabeça, mas não sabia como fazer, os africanos eram muito reservados, não falavam, e ele não pedia pro pai ensinar, talvez porque achava que o pai fosse viver para sempre, ou por medo de levar uma bronca. Meu avô e o amigo dele Claudino ficavam treinando um com o outro mas, não chamaram os filhos para treinar, eu fiquei com isso na cabeça, 'um dia eu vou saber isso também'.

[Com quem que o senhor aprendeu esse jogo, então?]

- Um amigo me deu um livro sobre Ifá, aí eu lia os odus e anotava em um caderno, os 16 odus maiores e os filhos deles [a combinação de um odu maior com outro maior gera um odu terceiro, tido como "filho dos odus que se combinaram"]. Quanto eu mais lia, mais mentalizava, lendo e gravando. Foi fácil demais para pegar, eu ia pela lógica, história do Brasil? Não existe lógica. Geografia? Não existe lógica, Matemática, não existe lógica, mas aí pelo Ifá existe lógica, então eu me guiava pela lógica, mesmo a de geografia, porque aí tem lógica mesmo, você vai mudar quem descobriu o Brasil? Na África, por exemplo, o Odu oworin e oxe têm numerações diferentes, são sete e oito, muita gente que está aqui não conhece, mas o que dá esses odus? 82 e é esse outro odu, não é o mesmo. Oworin é o Pai e Oxé é o filho, oworin oxé é filho de Oworin meji. Essas coisas eu já sabia, eu já tinha isso, mas quando eu li o livro essas coisas se encaixaram, se retificaram. Mas veio, sobretudo, por herança espiritual familiar. Da mediunidade, da intuição, tá entendendo? Porque as vezes a pessoa tá com vontade de ir por aqui, o que vai ser? Como será? Só que tem a mediunidade, não quer aceitar a coisa como deve ser. Aí você escuta é pra ir por ali e você diz não, eu quero ir por aqui, aí quebra a cara. Siga sua intuição, então a pessoa deve confiar somente nela, se livrar da dependência das pessoas, ser independente. Senão a pessoa fala eu vou fazer só o que fulano tá dizendo, aí se lasca! Aí tem que ir confiar em Deus, nos orixás, nos antepassados todos e em você próprio, o lema é esse! Confie, jogue e fale, invoque e jogue, que você vai ver, porque o orixá vai dar o recado, mas depende das invocações, da mediunidade. Porque o cabra só lê por lê[ fala do livro], mas quando tem de ser persistente, vai e vai, vai e vai e consegue. ”

O jogo de búzios em Recife, conforme descrito anteriormente, é geralmente consultado na modalidade de 16 búzios, conhecida por Erindilogum (Halloy, 2005; Carvalho, 1984). René Ribeiro, que conduziu a sua investigação etnográfica entre os finais dos anos quarenta e meados dos cinquenta do século passado, afirmava que "Em Recife, muitos sistemas de adivinhação são conhecidos e utilizados diariamente - Ifá e Exu, este último conhecido por sua qualidade, atua como um mensageiro dos deuses, que aqui tem um papel mais proeminente”. (RIBEIRO, 1978, p. 88). 
Segundo o autor, haveria tido, em Recife, os especialistas em Ifá, chamados babalawos, que não transmitiram às gerações posteriores esses sistemas divinatórios. Ribeiro constata que, ao que parece, havia, nessa época, uma divisão de tarefas entre o babalaô e o babalorixá, a exemplo do que ocorreria na costa africana, contudo, com o desaparecimento dos babalaôs, coube aos babalorixás acumular essa função, "apegando-se porém a processos mais simples do que o do uso do opelê" ou “improvisando outros sistemas”. Diz ele: "nenhum dos sacerdotes atuais [década de 5o] no Recife, tem "mão de Ifá"(ou seja, foi treinado e iniciado em funções de adivinho), "embora um deles, pelo menos recorde perfeitamente o método e alguns dos odu[...]” (1978, p. 88).

Pai Paulo adverte que, embora se tratando de jogos sob o domínio de Ifá, sua dinâmica de sua execução, seu manejo técnico e sua própria constituição “cosmológica” se modificariam através de suas diferentes execuções. Tais práticas diversas não seriam variedades de um mesmo jogo ou, como apontam alguns autores (Prandi, 1994, et al.), “técnicas simplificadas” de um mesmo jogo. Tratar-seia, de fato, de jogos que mediam a comunicação entre homens e orixás de maneiras distintas, manejando essas composições de acordo com seu próprio universo conceitual.

Cada modalidade de jogo de búzios (com dezesseis, oito ou quatro) no nagô possui uma dinâmica própria de manuseio e obtenção de respostas relacionadas aos contextos de sua execução. É conhecido, ainda, em Recife, um jogo de búzios da jurema³, que não tive oportunidade de acompanhar com mais detalhe, no qual há uma mudança da técnica do jogo e dos búzios em si (um tipo de concha mais escura), e ausência de odus. São jogos diferentes que se relacionam de uma maneira muito específica na composição de seus recados e de acordo com suas especificidades, os jogos de búzios performam 4 [enact] jogos diferentes.

\section{Compondo com caroços de dendê}

Pai Paulo, ao ler o livro “Ifá orixá do destino" (1995), entrou em contato com o sistema de jogo de Ifá nigeriano, composto por dezesseis odus maiores, odu-meji, que combinados entre si geram 240 odus menores, os omo-odu. Foram essas informações sobre os odus que atraíram a atenção de Pai Paulo, que ficou fascinado pela possibilidade em recuperar a organização dos odus e suas variações.

\footnotetext{
${ }^{3}$ Jurema é uma religião afro-brasileira muito popular em Recife e em outros estados.

${ }^{4}$ Opto pela tradução de "enact" por "perfomar", o uso do conceito é influenciado pelo trabalho de Annemarie Moll "Política ontológica. Algumas ideias e várias perguntas" (2012). Como nota o tradutor, o termo "enactment" está próximo da ideia de "performance". Ainda de acordo com o tradutor: "Em obras posteriores, a autora viria a adotar, em exclusivo, o termo 'enact', para se destacar de algumas conotações alimentadas pela extensiva utilização do vocabulário da 'performance', nas ciências sociais da viragem do século. O termo 'enact' é de complicada tradução para a generalidade das línguas europeias, sendo difícil cobrir todas as acepções com a elegância da palavra inglesa” (2012, p.7, nota 11.) Sobre a relação entre esses termos, cf. Annemarie Mol (2004), The Body Multiple, Durham e Londres: Duke University Press; e John Law (2004), After Method: Mess in Social Research,
} Londres: Routledge, p. 159. 
De acordo com os estudos sobre Ifá na Nigéria (ABIMBOLA, 1977; BASCOM, 1969; APTER, 1992; BARBER, 1989, entre outros), o odu só se torna visível aos olhos do babalawo pelas marcas que este faz no iyerosun. Segundo Félix Ayoh Omidire (2006), Odù seria um "volume" em que se encontrariam todas as informações que explicam os acontecimentos da vida. De acordo com ele, o termo Odù decorre de Olofin-Odù, nome de uma das mulheres do próprio Orúnmìlà. Essa esposa ajudava Orúnmilà em todos os seus trabalhos, o que a levou a se tornar a própria força com que ele conseguia cumprir as suas funções de conselheiro entres os humanos e os orixás (AYOH'OMIDIRE, 2006).

Os Odùs são desenhados sempre da direita para a esquerda, dessas 256 combinações possíveis, 16 se repetem em colunas idênticas, são os duplos, ou em ioruba, Meji. Em Ifé são na ordem: Eji Ogbe, Oyeku Meji Iwori Meji Edi Meji Obara Meji Okanran Meji Irosun Meji Owonrin Meji OgundaMeji OsaMeji Irete Meji OturaMeji OturuponMeji IkaMeji Ose Meji Ofun Meji

\section{Quadro 1: ordem dos Odùs}

\begin{tabular}{|c|c|c|c|c|c|c|c|}
\hline $\begin{array}{l}\text { Ogbe } \\
\text { Meji }\end{array}$ & $\begin{array}{l}\text { Oyeku } \\
\text { Meji }\end{array}$ & $\begin{array}{l}\text { Iwori } \\
\text { Meji }\end{array}$ & $\begin{array}{l}\text { Edi } \\
\text { Meji }\end{array}$ & $\begin{array}{l}\text { Obara } \\
\text { Meji }\end{array}$ & $\begin{array}{l}\text { Okanran } \\
\text { Meji }\end{array}$ & $\begin{array}{l}\text { Irosun } \\
\text { Meji }\end{array}$ & $\begin{array}{l}\text { Owonrin } \\
\text { Meji }\end{array}$ \\
\hline I I & $\begin{array}{ll}\text { II } & \text { II }\end{array}$ & $\begin{array}{ll}\text { II } & \text { II }\end{array}$ & $\begin{array}{ll}\text { I } & \text { I }\end{array}$ & $\begin{array}{ll} & \text { I }\end{array}$ & $\begin{array}{ll}\text { II } & \text { II }\end{array}$ & I I & II II \\
\hline I I & II II & I I & II II & II II & II II & I I & II II \\
\hline I I & II II & I I & II II & II II & II II & II II & I I \\
\hline I I & II II & II II & I I & II II & I I & II II & I I \\
\hline Ogunda & Osa & Irete & Otura & Oturupon & Ika Meji & Ose & Ofun \\
\hline Meji & Meji & Meji & Meji & Meji & & Meji & Meji \\
\hline I I & II II & I I I & I I & II II & II II & I & II II \\
\hline I I & I I & I I & II II & II II & I I & II II & I \\
\hline I I & I I & II II & I I & I & II II & I I & II II \\
\hline II II & I I & I I & I I & II II & II II & II II & I I \\
\hline
\end{tabular}

Fonte: Autoria própria 
O jogo de Pai Paulo mobiliza uma série de objetos em sua execução. A descrição desses objetos é encontrada no livro de Mestre Itaoman, “Ifá, orixá do destino" (1995). Esse trabalho é fruto de uma pesquisa do autor em diversos textos etnográficos sobre Ifá na costa ocidental africana. Contudo, no interior do texto, não há referência a que obras ou quais passagens o autor está citando. Esse tipo de uso da literatura antropológica por teóricos é recorrente em outros trabalhos 5 e mereceriam nesse trabalho um estudo, em profundidade, sobre citação e constituição textual, objetivos que me escapam nesta dissertação. Mas, de todo modo, os principais trabalhos de referência ${ }^{6}$ são os de Abimbola (1969) e Bascom (1960).

O principal elemento do jogo de Ifá seria o Ikin, o caroço de dendê, em especial o com quatro furos, ou "olhos". Pai Paulo me conta que conseguiu os seus com um filho de santo que mora na Ilha de Itamaracá-PE, lugar que teria uma grande quantidade de dendezeiros.

Após manipular os ikins, Pai Paulo obtém uma sequência de números ímpares ou pares em sua mão, traçando, então, um ou dois traços no opom (tábua de madeira), sobre a qual ele espalhou iyerosun, um pó de madeira amarelo. Os traços invertem o número de ikins restantes na mão de Pai Paulo. Dois traços denotam um número ímpar, um traço o número par.

Com o odu traçado, Pai Paulo anota no papel essa configuração. É preciso saber como "fala” e o que "fala" esse odu. Nesse momento, ele utiliza o opelê, o "auxiliar do opom", como Pai Paulo se refere. Ele joga, então, uma sucessão de vezes a corrente na esteira e vai escrevendo no caderno a combinação das caídas.

Nessa etapa, ele inquire o jogo orientado por uma sequência específica de perguntas, elas determinam se o jogo "está vendo bem” ou se “está vendo mal”. Essa visão do jogo determinará as categorias sobre o que ele pergunta, no caso de uma visão positiva, as perguntas serão sobre: vida longa ou não morte (ayku), dinheiro (aje, ọwọ), casamento (aya, iyawô), filhos (ọmọ) e vitória (işegun) sobre os inimigos. Cada questão dessas é especificada por determinados objetos os quais o opelê deve tocar, eles são: uma pequena pedra (Ọkuta), dois búzios (ọwọ) atados juntos, a extremidades da concha de um caracol (igbin), um osso, ou melhor, uma vértebra de um carneiro ou bode (egun), e um caco (apadi) de louça. De modo análogo, caso o jogo "não esteja vendo bem”,

${ }^{5}$ Conferir: Silva, 2000; 1995; Castillo, 2008; Opipari, 2010.

${ }^{6}$ A referência a trabalhos sobre Ifá entre os iorubas, apresenta-se apenas como sugestão de comparação, e não como explicação sobre Ifá em Recife. Pretendo evitar o uso de etnografias iorubas para "explicar" praticas religiosas do candomblé, essa metodologia aprisiona as comunidades de terreiro em determinada perspectiva histórica, que busca recompor suas realidades sob a luz do que teria se "deturpado" ou "perdido". Para uma visão critica desse procedimento conferir: (Segato, 1995, p.68; Opipari, 2010, p. 81) 
há cinco perguntas sobre os infortúnios: morte (Iku), doença (Arun, Aisan), combate (Ijá), privação de dinheiro (Ajé, ọwọ) e perda (Ofun).

Cada objeto personifica uma situação de acordo com o "olhar do jogo”, esses objetos são inversos à correspondência mediada pelo objeto para "bom" e para o "mal":

Quadro 2: Objeto e mudança de perspectiva

\begin{tabular}{|l|l|l|}
\hline \multicolumn{1}{|c|}{ "Vendo Bem" } & \multicolumn{1}{|c|}{ Objeto } & \multicolumn{1}{c|}{ "Vendo mal" } \\
\hline Filho & Egum(osso) & Iku (morte) \\
\hline Casamento & Igbin (casca de caracol) & Aisan (doença) \\
\hline Vida Longa & Okuta (pedra) & Ija (lta, combate) \\
\hline Dinheiro & Owo (búzio) & Aje (carência) \\
\hline Vitória & Apadi (caco de louça) & Ofum (derrota) \\
\hline
\end{tabular}

Fonte: Autoria própria

Pai Paulo gosta sempre de reiterar que é preciso saber o que ofertar e a quem ofertar. Essa é a última parte da consulta e, novamente, os objetos são estendidos a outro contexto. Personificando cada uma dessas novas possibilidades, os destinatários dessas oferendas seriam: os ancestrais (eguns), as divindades (orixás), Orumilá (Ifá), Ori (cabeça), Ipako (espiritualidade).

Quadro 3: Seres e Objetos

\begin{tabular}{|l|l|}
\hline Seres & Objetos \\
\hline Ipako & Caco \\
\hline Cabeça & Pedra \\
\hline Ifá & Búzios \\
\hline Orixás & Caracol \\
\hline Ancestral & Osso \\
\hline
\end{tabular}

Fonte: Autoria própria

Essa ordenação das caídas é determinada pela sequência dos odus que são obtidos em cada uma delas, os odus seriam conhecidos como os filhos de Orumilá e teriam vindo do orun para o aiye. 
Essa passagem foi feita por cada odu em um momento distinto, o que levou a organizá-los de acordo com o tempo de chegada de cada um. O primeiro odu a vir seria Ogbe e o último Ofun. Para iorubas, Ofun é o odu mais velho e, por isso, veio por último. Por ser o primeiro, o odu Ogbe é considerado o "mais velho" dentre os odus, e por ser o último a chegar na terra (aiye), Ofum seria o mais novo. No caso de Ofun, há uma inversão, Ofum passou de mais velho a mais novo, por causa dessa passagem, uma vez que por ser muito velho demorou-se na passagem do orum para o aiye. A ordem de chegada dos odus determina sua organização e os hierarquiza (AYOH’OMIDIRE, 2006).

Cada pergunta sobre os infortúnios ou bonanças corresponde a duas jogadas do opelê. Os odus resultantes da jogada são analisados de acordo com o princípio de senioridade, quanto menor um odu na escala de seu surgimento (dos primeiros seriam os dezesseis odus pais, seguidos pelas 240 combinações possíveis), mais velho ele seria, quanto maior seria mais novo. Contudo, essa hierarquia é alterada de acordo com determinadas inversões dos odus, como no caso da relação Ofum-Oworin, e outros. Alguns odus ainda possuiriam a capacidade de serem considerados como de "valor determinante", quando eles saem, não precisam de uma segunda jogada para saber se ele ganha ou perde na hierarquia, é o caso do odu Ogbe-meji, que teria valor absoluto (maior confirmação), e outros, como Ofum-Meji, Ogunda-Ogbe (COSTA,1995, p. 142).

Os Odùs guardariam em seu interior os segredos do mundo e somente os babalawos teriam acesso a eles durante sua vivência e aprendizado no culto de Ifá. Conhecer os odus é cultuar Ifá.

Um dos principais autores a trabalharem com o estudo sistemático de Ifá, por meio da análise dos Odùs, foi o Professor e Babalawo Wande Abímbólá. Para ele, Ifá poderia ser entendido como um corpus literário da cultura iorubana.

O corpus literário de Ifá é, de longe, o gênero mais rico da poesia oral Yorùbá. Ele é dividido em 256 categorias conhecidas como Odù, dos quais os primeiros dezesseis são considerados maiores, e os duzentos e quarenta restantes como Odù menores. Cada Odù contém um número não especificado de poemas conhecidos como ese. O trabalho do investigador presente, ao longo dos últimos seis anos, revelou que há várias centenas de ese existentes em cada Odù (ABIMBOLA,1976.p,72, tradução de Ayoh Omidire, 2006, p. 143).

Wande Abimbola continua destacando que, se por um lado os números dos Odùs e suas combinações são amplamente conhecidos pelos seguidores de Ifá, a ponto de nenhum babalawo ter 
dificuldade em reconhecer qual odu aparece marcado no iyerosun, o mesmo não conhece com os ese que cada odu traz em seu interior (ABIMBOLA, 1976).

Entretanto, o livro "Ifá orixá do destino" não oferece mais do que um verso sobre os principais odus. Pai Paulo precisou, então, recompor o sistema de Ifá, os versos que não possuía, os quais, segundo ele, seu pai e seus tios não aprenderam com seu avô. A leitura serviu como esse gatilho, mas Pai Paulo não se contentou com o que encontrou escrito naquelas páginas. Foi preciso ir além:

“Todo dia de manhã eu jogava Ifá e dava um odu, aí eu saia para caminhar e ia ouvindo o que as pessoas falavam, o que eu via acontecer no caminho, e aí vinha uma frase aqui, eu anotava uma coisa ali, uma resposta, e quando chegava em casa anotava tudo e comparava, eu queria ver se tava certo com o que o odu diz, se batia, sempre batia. Foi com isso que me curei, meu nome de Ifá é Ifatóògún [Ifá foi seu remédio, ou o curou]. Fui curado por Ifá”.

Arnaud Halloy estava em Recife, realizando seu trabalho de campo para sua tese, e acompanhou esse primeiro momento de "escuta do mundo" para registrar os versos de Ifá:

Paulo possui, assim, seu "livro de ouro", um grande caderno em que, para cada página, tem o número do seu odu correspondente e as "mensagens" extraídas ao longo de suas caminhadas de toda manhã, no alvorecer, conforme aconselhamento médico. Ele "joga" a fim de descobrir a configuração do dia, o oni odu. Ele abre seu caderno, na página correspondente, e sai para caminhar. No curso de sua caminhada, ele prestara particularmente atenção aos sons, sejam fragmentos de conversas ouvidas, ruídos confusos, o murmurar do vento, ou ainda àquilo que ele pôde ver durante a caminhada. Essas informações fragmentares são a matéria-prima para recompor cada uma de suas peças do quebra-cabeça. Quando "sai" um odu que já contém seus "novos versos", eles poderão ser complementados com as novas informações ou poderão ser deixados como estavam, se nada de novo apareceu (Hallouy, 2006, p. 638, tradução minha).

Quando cheguei a Recife, esse caderno já tinha se completado. Pai Paulo me disse que ele estava bruto, que agora ele já lapidara seu conteúdo e era com ele que escrevia os recados de Ifá:

“Ali está o bruto, não tá os versos. Eu saía para rua após o jogo, para confirmar o que o jogo falava. Desvendar o oculto. Então eu passava numa rua e uma pessoa falava: 'deu tudo certo com o negócio’. Outras vezes, aparecia um cachorro no meio do caminho. Eu levava um caderninho e ia 
anotando tudo. Mas aquilo era bruto. Aquilo era o que eu estava enxergando... Mas tem de colocar aquilo no lugar, colocar em ordem, é preciso ainda ler, averiguar e extrair o que estava correto de acordo com o jogo. De acordo com as intuições, ganhar do oculto. Ver de acordo com o segmento, então têm de traduzir e colocar em verso. No recado está mais puro, o odu pode se transformar em verso e aí está dizendo o que é. Hoje, o recado já sai melhor, está lapidado. Eu escrevo em poucas linhas. Sempre foi assim, quando eu era gerente no Banco Itaú, meus memorandos eram escritos em poucas palavras. Quem sabe o que quer dizer não precisa de muito para escrever. Sempre fui assim, até na escola. Então, o recado hoje sai mais preciso, mais direto. Mas ali não está tudo, eu não dou ouro ao bandido. A pessoa que ler precisa ver o que o jogo diz pra ela, a partir do recado do dia. O que está ali é o coletivo, agora, cada um precisa ver o que é seu naquilo. Um dia estava andando com minha mulher, ela estava preocupada porque seu irmão estava muito doente. Ao passar na rua, vi uma criança falando pra outra 'até amanhã'. Eu falei pra ela que meu cunhado ia morrer no outro dia. Ela brigou comigo. No outro dia o irmão faleceu... 'Bi ôwé bi ôwé ni Ifá soro’é por meio de provérbios e na forma de exemplos que Ifá fala."

Atualmente, Pai Paulo não lê mais o caderno para ver o recado do Odu. Quando ele joga, não recorre mais ao caderno para ver o que corresponde nas histórias do odu, pois já "Está tudo aqui na minha cabeça, os odus driblaram minha trombose”, disse-me sorrindo.

Para compor o recado, Pai Paulo parte das jogadas. Primeiro, com os ikins ele tira o "odu do dia”, anota no caderno. Depois ele utiliza o opelê (o auxiliar do opom, como ele sempre diz), para ver se o jogo "está vendo de bem" ou se "está vendo de mal”. Só então ele parte para as perguntas que cada uma dessas possibilidades permite. Cada pergunta questiona o jogo sobre as sortes ou infortúnios, o que eles permitem saber sobre saúde, emprego, família, dinheiro. A cada questão dessas, é realizada uma nova jogada que compõe dois odus. Esses odus devem ser lidos pela "ordem das hierarquias", para saber "qual que está ganhando", e só assim saber a mensagem de sua caída. Essas combinações também são anotadas em sequência, no caderno. Só aí é que Pai Paulo procede à leitura do jogo e à elaboração do recado.

\section{Multiplicidade e variação nos Recados de Ifá}

Diariamente Pai Paulo joga Ifá e anota seu recado. Como ele mora em João Pessoa e o restante de sua família em Recife, pediu ajuda a um amigo e criou um website, o “http://paulobrazalapini.webnode.com.br/", para registrar o recado de Ifá. O site serve como um “ensinamento" para quem o acessa, informando sobre como será o dia. Ali, Pai Paulo registra seus 
recados de forma abreviada, sem colocar o odu correspondente ao ensinamento: "Isso já é o mistério, não posso revelar para as pessoas”. Na página, Pai Paulo oferece um pequeno guia para informar as pessoas sobre o seu sistema de recados de Ifá:

"Mantendo uma tradição familiar africana o Awo Paulo Braz resgatou este oráculo primando pela ancestralidade de Ile Ifé, berço da cultura Yorubana. Sendo que, são 16 Odus Pais que tem 16 filhos cada um formando o número de 256 odus e cada odu citando 16 versos chegando a um total de 4096 versos, que devem estar presentes na mente do Babalawo. Portanto a leitura destes versos pode confundir a cabeça de pessoas que não nasceram com este dom e além de tudo não dedicaram parte da vida para avançar neste sentido. Todos os dias Ifá é consultado e seus odus determinam versos que são traduzidos, observando os infortúnios e as boas sortes, e assim são produzidos os recados aqui apresentados de forma sucinta. Vale salientar que em cada verso, original, existe a solução para os problemas. Neste sentido você poderá entrar em contato conoscoe conhecer melhor os detalhes que possam ser identificados individualmente e assim solucionar seus infortúnios.” (Disponível em: <http://paulobrazalapini.webnode.com.br> Acesso em: 14 jan. 2014).

Os sítios se multiplicaram7, neles, encontramos diariamente os "recados de Ifá para o dia de hoje”, nesses recados, encontramos narrativas que foram transpostas para o papel, e posteriormente transcritas para aparecerem na internert. Eles são escritos a partir de sua articulação com os resultados das jogadas do opelê e com a disposição de eventos das “memórias” de Pai Paulo, que são relativos aos componentes dos recados e confirmam-se nas situações dos consulentes. Como veremos, esses recados possuem uma relação direta com a eficácia ritual. Encontramos nesses recados uma intenção comunicativa na produção desse repertório de versos que resultam da relação de "tradução" das caídas do jogo de Ifá a partir da experiência de Pai Paulo.

Durante o trabalho de campo e as leituras desses recados diários, pude notar que a frequência das postagens desses recados reflete o dia a dia de Paulo Braz. Quando ele está em Recife, ou em

\footnotetext{
${ }^{7}$ Além do seu primeiro site, Pai Paulo criou outras páginas para postar os recados de Ifá, cada página recebeu um nome em alusão a um ancestral, como um site homenageando seu avô Adão, outro seu Pai Malaquias, e outro seu tio José Romão. Contudo, essas páginas deixaram de ser atualizadas com tanta frequência, a justificativa que Pai Paulo me deu é que ele precisa "improvisar bem" para sair recados diferentes sobre uma mesma configuração de odus, o que demandava muito esforço e criatividade.
} 
outros lugares, realizando "obrigações de santo" ou outras tarefas, os recados não são colocados no site. É apenas quando ele está em sua casa de João Pessoa, na tranquilidade de sua rotina, que ele se dedica à essa tarefa. Dessa forma, através das postagens no próprio site, pude acompanhar os deslocamentos e interrupções em seu cotidiano.

Outra característica desses recados é a incidência de acontecimentos cotidianos de Pai Paulo, retratados no conteúdo dos recados, como, por exemplo, no dia 27 de dezembro de 2013, quando encontrei Pai Paulo reclamando de que estava com problemas intestinais e não sabia o que era. No dia seguinte, leio, em sua página na web, o que o recado de Ifá lhe advertia:

\section{RECADO DE IFÁ HOJE 27.12.2.2138}

Ifá fala de germes na água, provocam uma diarreias persistente, ou bactérias perigosas que muitas vezes prejudicam seriamente a saúde das pessoas., Ifá não está vendo nada bem, A situação desagradável, não desaparecem com facilidades. Os infortúnios vêm falando de doenças de altos riscos, lutando para evitar a morte e a falta de dinheiro, para combater as possíveis as derrota (Disponível em: <http://paulobrazalapini.webnode.com.br> Acesso em: 10 jan. 2014).

Entretanto, se, à primeira vista, pode-se pensar que os recados partam de questionamentos diretos sobre a vida de Pai Paulo, estaria se incorrendo em um grave equívoco. O recado, ao contrário do que se pode pensar, nunca é para ele. Ele me disse que nenhuma pessoa deve jogar para si, pois caso o faça, poderia manipular o jogo e afetar o resultado das jogadas. É por isso que Ajibola, por exemplo, procura confirmar o seu próprio jogo com o de Pai Paulo:

“Eu não jogo para mim, poderia influenciar o jogo. Por isso que Ajibola confirma o jogo dele comigo. Ajibola joga com búzios, eu com Ifá. O jogo de búzios dá um número limitado de odus, não possui todos eles. Para saber sobre cada coisa, é preciso várias jogadas, enquanto com o opelê eu jogo uma vez e consigo o recado. Ajibola não joga com ikins, ele usa até cartas [risos]. Eu prefiro o opom e opelê. Mas ele diz que "tudo é matemática". Eu não confio em qualquer pessoa para jogar e isso é ruim. Não posso nunca jogar para mim. O jogo não funciona para você mesmo. Quando fomos para Nigéria o ano passado [2013], Ajibola apareceu um dia com um Babalawo. Ele queria que eu jogasse com ele, que ele poderia curar minhas pernas. Eu falei tá bom, mas só se ele bater Ifá comigo e a minha jogada confirmar a dele, e assim por diante. Para saber se ele fala a verdade ou está só de enrolação. Meu jogo

\footnotetext{
${ }^{8}$ Opto por Transcrever literalmente os recados de Ifá, não efetuando alterações na maneira como Pai Paulo os escreve.
} 
vem de herança familiar. Como o rei de Oyo falou pra mim: 'Você fala ioruba arcaico. Foi preciso alguém vir lá do outro lado do oceano para cantar para mãe de Xangô. Se tiver seis africanos que sabem o nome da mãe de Xangô, é muito’. E eu sabia! Essas coisas ninguém me ensinou. Por isso não posso ensinar ninguém a jogar Ifá, como vou passar para alguém aquilo que não aprendi? Isso vem das intuições, de herança. De Deus, dos orixás, de meu bisavô Adifabola. Do egum de nossa adoração Baba Okoto. Tá no nosso sangue. Quem é bom já nasce feito!"

De toda forma, os recados se não são diretamente para ele, podem refletir lições e conselhos de Ifá para sua família a partir de suas preucupações, como, por exemplo, nos recados posteriores à festa de Iemanjá (ocorrida no dia 19/12/2013), na qual aconteceu uma briga por causa de uma foto que alguém tirou de Iemanjá e ela não gostou. Não havia chegado a Recife quando essa festa ocorreu, mas desde os primeiros dias em que estava na casa de Mãe Lú, ela era motivo de conversas sobre o que havia ocorrido. Cada um interpretava o ocorrido de uma forma diferente, Pai Paulo receava que as conversas e atritos saíssem do âmbito reservado da família e chegassem a discussões acaloradas em sites de relacionamento. Esses eventos deixaram Pai Paulo bastante apreensivo, uma vez que, ao se tornarem públicas aquelas informações, ele temia pelo "nome da família”. Sobre isso aconselhou Ifá:

\section{RECADO DE IFÁ HOJE 24.12,2,013}

Olofin Odudua criou Ifá para conservar, este grupo étnico, fundado por ele para todas as divindades, com dignidades e muitos respeitos. Eró, foi designado para saber através das consultas, se os adeptos, ainda estão seguindo os mesmos fundamentos inicial;

Oba Afinulode, traduzindo o recado, falou que tudo está modificado, Ao iniciar as oferendas, já estão procurando saber quantos dias ficarão de resguardo, Não procuram saber qual a oferenda se é ebó ou adimu sacrificio; O que ofertar as divindades; Ou a quem ofertar. Muitas vezes, o Orixá só quer água, e lhe oferecem um boi. A oferenda não deu certo porque não lhe deram a água e a oferenda não foi aceita, porque lhe deram um boi que ele não queria A adoração está sendo feita mais em função do dinheuro do que do amor ao Orixá; Brigas, esculhambações entre familiares, atos amorosos entre sexo do mesmo sexo, Ifá não está com preconceito, só está falando do derrespeitos as divindades. 
Dificilmente, cantan-se Caruani ${ }^{9}$, que é para ganhar tempo para sacrificar o próximo, quando o animal anterior ainda está se debatendo. As boas sortes, vem trazendo um dia vitorioso, com alegrias de poder ter filho ou mais, Terá uma situação financeira controlada; E na velhice, deverá existir no casamento mais conpreemção entre o casal, evitando pequenos atritos entre o casal, evitando pequenos atritos, para alegrias e felicidades nas relações amorosas (Idem).

Por meio dessa história, Pai Paulo transcreve por meio de metáforas aquilo que lhe diz Ifá sobre o diagnóstico de determinada situação, em seu dizer, "por meio de provérbios e na forma de exemplo é assim que fala Ifá”. Como podemos ver, essas histórias são importantes pelo conteúdo e principalmente efeitos que produzem em seus leitores. Pai Paulo é um grande contador das histórias de seus ancestrais, mas a composição dos recados não se resume a isso, de todo modo, dessas narrativas em composição com aquilo que fala o jogo que ele parte de modo criativo para aconselhar quem o procura ou lê, bem como, exprime suas censuras ao não cumprimento das obrigações rituais, a partir daquilo que enxergaria Ifá. Dessa forma, os recados ganham seus contornos de acordo com o contexto em que as perguntas lhe foram dirigidas.

Por exemplo, para escrever na forma de versos aquilo que diz Ifá, Pai Paulo pode iniciar de uma situação mais especifica, como uma questão em particular ou uma determinada situação. Cada jogada do opelê corresponde a um verso, e esse verso pode comunicar a um outro conjunto de questões, que podem ou não estar relacionadas a primeira questão que abriu o jogo, isso deve-se, em parte, ao fato de que os recados de ifá que estão na internet, tendem a não ter um destinatário específico, abrangendo uma infinidade de situações para exprimir sua mensagem, como no caso abaixo.

\section{RECADO DE IFÁ HOJE 17.11.2.014}

\section{Ésé Itan ifá}

Adimula, foi que criou Ifá, para ver se Aboni, teria boas sortes;

Aboni, através das consultas, soube de Ifá, que vai ganhar, este já está ganho;

\footnotetext{
${ }^{9}$ Segundo Pai Paulo, nessa passagem, Ifá diz sobre a última cantiga dos sacrifícios que as pessoas não cantariam mais para poder passar para o próximo santo durante as obrigações. Sobre essa cantiga, ver cantiga 20 dos sacrifícios em (CARVALHO, 1993, p.158.)
} 
Está fechado, O Bandeirante, não tem outra saida, a não ser pagar a sua indenização;

Oku Ajá adverte para evitar pessoas com energias negativas;

Não respeitam ninguém e tem muito o que pagar;

Não olha as humildades das pessoas, provocando intrigas,

com racismo, e com, desentendimentos, sem ter prazer, no casamento;

Humilhando as pessoas, e ninguém sabe o dia do amanhã;

Ifá diz que na Aruanda, não ouvirá o que ele diz;

É viciado em geral com bebidas alcoólicas, quando bebe,

fica como um louco, não atende ningúem;

Deve ter cuidado com acidente, pincipalmente,

nas curvas das avenidas;

Jogue na loteria, com sorte poderá ser premiado;

Ifá fala das boas sortes, com vitórias sobre doenças,

com alto riscos de vida;

Terá liberação de dinheiro; na velhice, haverá, incompatibilidade entre o casal; $\mathrm{O}$ casamento com amor está abalado;

Deve agradecer a Sangòó, para ter amor e harmonias, com afeto entre os pais e filhos, para combater as crises e para se tornar uma família feliz.

Esses recados obedecem a uma armação que varia conforme a mensagem a ser transmitida. Por vezes, os recados começam por "Ifá diz" ou “Ifá não está vendo bem hoje”. Isso nos indica se os Odus vêm por "bons ou maus caminhos", ou seja, se os recados são positivos para quem pergunta ou não. Em outros, os recados contêm na abertura o nome do Odu, por meio do qual o verso fala, essa codificação permite aos iniciados do candomblé saberem quais são as prescrições contidas em cada odu.

RECADO DE IFÁ HOJE 18.11.2.014

Ésé Itan Ifá 
Araba, criou Ifá para Akanji fazer reuniões,

para se previnir de uma morte repentina,

quando estava bem se saúde;

Akanji consultou Ifá que falou, que existem esquemas violentos,

dos bandidos, roubando e desviando com lavagem de dinheiro,

com o fim de investir na política, para beneficiar candadto,

para assumir cargos eletivos;

Não se preocupam na educação e na saúde,

quando muitas pessoas morrem por omissão de socorro médico.

Sem contar com as dificuldades humanas, que muitas vezes,

lutam para ter dinheiro para conseguir comprar o pão de cada dia.

Os infortúnios, vem trazendo falta de dinheiro sem condições de comprar medicamentos,

As doenças dos idosos. que sofreram quedas.quebrando membros importantes do corpo;

Não deve brigar para não se arrepemder; Existem acompanhamento espirituais, podendo até ver dois vultos, conforme a sua vidência.

As narrativas podem reportar-se a um contexto mais amplo, nesse caso, ela reporta-se a problemas que uma pessoa possa estar vivendo em consequência da situação política ou econômica do país, acesso a terra, ou luta contra o racismo, entre outras. Um modo de análise dessas situações, a partir de Ifá, é uma leitura reversa desses problemas.

RECADO DE IFÁ HOJE 20.01.2015

Ifá fala que não estão respeitando a democracia

os menos favorecidos se pegar um chocolate

é condenado a 20 ou 30 anos de xadrez

enquanto os ladrões de gravata estão palitando o dente.

Ifá dos infortunios no passado,

iniciou uma nova etapa na vida; 
o momento pode ser de novidades;

Ifá não está falando do bem;

tudo o que faz não ve bons resultados;

não está vendendo como não esta podendo comprar.

Os infortunios vem trazendo falta de dinheiro

para poder cumprir seus compromissos financeiros

a ponto de contrair graves doenças;

deverá lutar para ter uma paz mundial

para o bem estar da humanidade

matando pessoas inocentes, usando as derrotas

com requintes de maldição com crueldade.

Ifá pergunta porque não procura com afinco

e urgentissimo vacinas para curar sérias doenças

como o cancer , hiv, ebola e muitas outras escondidas embaixo do pano

ao invés de fabricar poderosas armas

deixando muitas mães chorando

pelos desaparecimentos dos seus filhos queridos.

Ifá diz ainda que os rombos existentes

nos mensalões, pretoleiros, os ladrões de gravata

estão fazendo fata a saude, os doentes necessitando ser atendidos nos postos de saude

estão ficando sem um medicamento muito importante que é insulina e seringas que falta mais de 6 meses aos necessitados.

O mesmo acontece com a educação, as crianças mal formadas com ensino muito precario.

Há ainda os recados que determinam o ano do terreiro, ou seja, qual odu que ira presidir a vida das pessoas que habitam a casa de Iemanjá Ogunté, o "odum odu”. Toda virada de ano, próximo a meia noite, toda a família se concentra em volta da cozinha do terreiro, em meio aos preparativos da ceia de ano-novo, alguns pratos com ebô para Orixalá são preparados e colocados nos assentamentos. Concomitante a isso Pai Paulo estende sua esteira e inicia as invocações para Orumilá, avisado pelo crescente barulho de fogos, ele procede ao jogo assim que o relógio marca meia-noite para determinar 
como será o ano da comunidade que Ifá irá lhe mostrar pelo odu sair em seu jogo. Todos os presentes sentam-se a sua volta e acompanham com atenção o resultado do jogo. Após esse primeiro jogo, ele na manhã do primeiro dia do ano, irá finalizar o jogo após "ganhar do oculto" e elaborar o recado. Pude acompanhar dois jogos desse, nos anos de 2014 e 2015. Vejamos um recado para o ano:

Odu do ano 2015

Oturopan Meji

Quem comanda Iyemanja e Ibeji.

Esé Itan Ifá (versos de Ifá)

Oluwofin criou Ifá para Olokun conhecer o odu que vai reger o ano de 2015, e através da consulta soube que será o odu Oturopan Meji. Através de Iyemanjá Ogunte com Ibeji com as anuências dos ancestrais, Ogum, Oxóssi. Olokun soube também que o odu é intermediário ,o que um está sentindo o outro também sentirá as consequências.

Okotorojo foi avisado que será próspero recebendo as graças alcançadas e com emoções sem problemas no momento do parto e com felicidades no casamento. Mas quando fala do mau, diz que poderá haver separação, que as coisas estão paradas, se for comerciante não está vendendo, como também não está podendo comprar; quem segura a situação é Ibeji (ere) por causa do amor do filho e dos trabalhos e tudo caminharão bem.

Adaunse fala das boas sortes mas poderá haver intermediações no recado; elas virão trazendo nascimento de filho com boa saúde e inteligente, mas é preciso dar boa educação doméstica que será a entrada para fazer uma boa universidade.

Akinkanju está lutando para na velhice ter facilidade para fazer bons negócios ou investir no ramo da construção civil que poderá ter uma boa lucratividade. Não deverá ter duvida para não atrair energias negativas.

Adesian diz que fez ou fará bom casamento com boas relações amorosas; mas repentinamente como uma transformação perigosa tudo vai por agua abaixo, pelas intermediações dos odus. 
Vai recuperar uma coisa já perdida ou ameaçada de perde-las. É preciso união para não perder alguma coisa.

Ifá diz também que os caminhos virão trazendo abertura para felicidade com a proteção das espiritualidades; deve proteger a cabeça, o físico, o corpo e segurança espiritual. Deverá cultuar Ogum, por ser primogênito de Olofin Oduduwa com a união com Olokun. Odé(omo iya Ogun Onirê) e Oxampanã nosso Alaxé para poder viver muito feliz e tranquilo.

Axé , axé, axé

Baba Ifamuide. (http://alapinipaulobraz.webnode.com/odu-odun-2015/, acessado em , 04/01/2015)

A escrita dos recados obedece uma composição específica entre a jogada do ikin, o odu que aparece e a maneira de se transmitir o recado. São os odus e as situações que eles elicitam que são "traduzidas" por Pai Paulo por meio das conexões que ele estabelece em meio a participações envolvidas entre tais situações prescritas, orixás que as motivam e ancestrais que se vinculam a tais contextos, segundo Pai Paulo:

“O recado está mais puro, eu preciso traduzir e colocar em verso, o odu pode se transformar em verso e dizer o que é, os outros eu fiz e já tá aí, por exemplo, Obikule é uma filha de Obaluaiê, que tem o mesmo Obaluaiê que eu tenho, Sapatasi é Xapanã, já nos outros vem um egum, Alakeoman é um egum, Abilare é um egum, Araba... Atokun é o líder dos eguns nas invocações mesmo. Aí eu boto o nome, fulano consultou Ifá, criou Ifá para dizer através do Ifá o que está acontecendo, então soube o que está acontecendo, então, sobre o que tem de fazer, isso e aquilo. Isso é um verso depois que vem o recado, as boas sortes e os infortúnios. Eu boto o nome desse povo para poder criar o verso, eu tô fazendo do meu jeito. Adamassi é meu avô, chega o odu e daí o que eu vou dizer o primeiro odu, né? O primeiro odu que criou Ifá para saber aquilo, aquilo outro, depois vem o sim ou não, que já é o jogo”.

A exemplo de seus duplos na Nigéria e em $\mathrm{Cuba}^{10}$, os versos de Ifá iniciam com o nome do “impersonador” do recado. Se na Nigéria o nome é um diagnóstico do odu, em Recife pode ser um

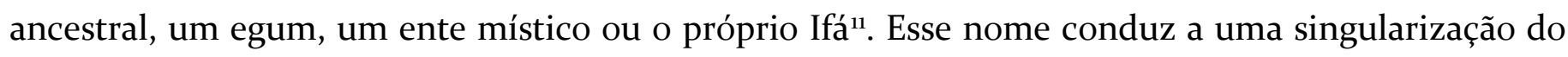
recado, de acordo com as combinações do odu, por meio de sua “impersonação". Nesse sentido,

10 Na Nigéria, conferir entre outros: BASCOM (1961), ABIMBOLA (1970), OMIDIRE (2006). E em Cuba cf.: HOLBRAAD (2013).

${ }^{11}$ Sobre o papel de Ifá figurar nessas narrativas como personificador, cf.: HOLBRAAD (2013). 
entendo a personificação de maneira análoga àquela descrita por Wagner (1972) sobre impersonation:

[impersonation]Impersonação envolve a assunção da identidade de um ser não apenas assumindo seu nome, mas adotando sua aparência, imitando seus maneirismos e, em geral, assumindo, de forma imitativa, aspectos culturalmente significantes de seu papel. Personificação adquire significado através da analogia suscitada por identidades ou papéis contrastantes, o de quem personifica e o do ser (pessoa, fantasma, divindades, etc.) que ele escolheu personificar. Quem personifica obtém sua vantagem (a força de sua inovação) através de capacidades 'externas' que a personificação acrescenta a ele. Assumindo a identidade e a personalidade de outro ser, ele também assume seus poderes especiais e agrega ao seu. Assim nós podemos falar de um fantasma, o qual sempre aparece como a personificação de um médium particular, como uma inovação sobre suas limitações particulares, e de fantasmas em geral como inovações sobre a mortalidade humana” (WAGNER, 1972, p. 26) ${ }^{12}$.

Parênteses: Nesse ponto, há uma ressalva a se fazer. Ao traduzir impersonation como “personificação", talvez não se consiga traduzir também a ambiguidade que seu sentido carrega em inglês. Impersonation também alude a uma capacidade de imitar, ou parodiar, aquilo que se personifica, um "embuste" ou "truque”, ou ainda, na linguagem do coyote, um "tricking magic" (WAGNER, 2010b, p.2). Esse "truque" permite que a personificação nunca ocorra por "completo". Transformando o parodiador em um ser exatamente idêntico àquele que se personifica, não há uma identidade a qual se aceda por meio da personificação. Esse movimento, portanto, é sempre ambíguo, incompleto e perigoso. A criatividade não pode ser controlada e, por isso, há sempre algo que escapa ou transborda quando circunscrita, o personificador sempre engaja os contextos transformando-os, mas os sentidos de sua personificação nunca saem exatamente como ele objetivara.

Não obstante, esse "truque” é necessário e esperado. Com os "personificadores" dos odus, encontramos essa ambiguidade existencial nos recados. Isso porque a mensagem não alude a uma “representação" da narrativa, há sempre espaço para uma nova contextualização que escapa do relato “original”. Bons jogadores são aqueles que conseguem antecipar o movimento do oponente, antecipar

\footnotetext{
12 Traduzido por Kelen Pessuto e Isabela Venturoza.
} 
suas técnicas e escolhas. O conceito de jogo de Ifá alude tanto ao movimento de jogar com búzios e ikins quanto de antecipar esses contextos ao interpretar o resultado dessas caídas, a partir do que fala o consulente. Uma reversão de seus significados por meio do coincidir de suas significações. Não se trata de assemelhar-se ao "personificador", mas de coincidir os eventos - estes, como afirma a teoria nativa, sempre se repetem e sempre se repetem com pequenas diferenças. Fecha parênteses.

Os recados narram de uma experiência vivida ou relembrada, escritas de modo a articular aquilo que o leitor ou leitora avalia com sua própria experiência (passada e presente). A partir dessa trama de Ifá que destinos ganham novas possibilidades.

\section{RECADO DE IFÁ HOJE 07.12.2.013}

Ifá diz para ver com quem anda ou para vai;

Ifá não está vendo bem; Muitas vezes está sem acompanhada,

por uma pessoa altamente com energias negativas.

Fala dos infortúnios; Lutar para vencer os grandes inimigos, que ameaçam a todos os momentos, provocando sérias doenças com resultados inevitáveis.(Idem)

\section{RECADO DE IFÁ HOJE o6.04.2.014}

Ifá fala do prazer para adquirir tudo o que deseja;

Ifá está falando do bom; Fala da tranquilidade, sem nenhum obstáculo, atrapalhando sem crescimento funcional. As boas sortes, vem trazendo ganhos ineperados, de dinheiro, nos esncontros dos caminhos da vida.(Idem)

\section{RECADO DE IFÁ HOJE 03.08.2.014}

Ifá fala de direitos humanos, materiais, espirituaus e da saúde que deseja também;

Ifá não está vendo bem; Fala de prazeres, ilusões, como também triângulo amoroso, briga e necessidades, de equilíbios. 
Os infortúnios, vem trazendo doenças de riscos, inclusivel, por ferimentos de faca ou de tiros:

Existem problemas de eegun, invejas e olhos grandes;

Deverá fazer linpezas espirituais e fazer consultas médicas, para afastar uma possivel morte prematura;

Confie em Deus que o caminho é este;

Não existe passado sem futuro. (Idem)

\section{RECADO DE IFÁ HOJE 31.03.2.014}

Ifá manda agradecer a vida passada, ocasião em o santo, ajudou bastante;

Ifá está vendo tudo bem; É como se encontra um amor, quando menos espera.

As boas sortes, virão através dos filhos, que na velhice, lhes darão muitas alegrias;

Fez ou fará um excelente casamento, com amor sincero;

Deverá controlar as despesas, para sempre ter dinheiro disponivel.(idem)

Em outras passagens, o nome do odu ou de Ifá é substituído por nomes dos ancestrais de Pai Paulo, ou de antigos sacerdotes do nagô pernambucano. Pude identificar esses nomes e pessoas através das narrativas que Pai Paulo me fez sobre seu avô Adão (que aparece nos recados como Ope, uma redução de seu nome ioruba Opewatanan) ou de Otolu, que era pai de criação de seu avô. No entanto, essa composição, não é algo derivado do que poderíamos denominar como "imaginação" ou “criatividade" individual, mas advém daquilo que Pai Paulo nomeia como "heranças espirituais”, essa herança seria um modo de relacionar esse seu conhecimento a partir de interlocução com diversos seres, tais como orixás, e, preferencialmente, os ancestrais. Tais motivações são ativadas por relações de parentesco (rituais ou consaguineo), como veremos a seguir:

\section{RECADO DE IFÁ HOJE 03.12.2.013}

Lakeoman, criou Ifá para fazer oferendas para eegunle;

Abilaré, fez a consulta aos ancentrais, que determinou, qual seria o ebó;

Otolu, foi indicado para fazer muitos akará com assadaka. 
Estas oferendas poderão trazer muitas sortes, no casamento, gerando bons filhos inteligentes, com vitórias nos ganhos de dinheiro, para na velhice, viver bem financeiramente.

Alguns recados contém os nomes de outro sacerdote de Ifá importante, Martiniano Eliseu do Bonfim "Ojelade", bem como seus pais, eles figuram como personagens das histórias contidas nos ensinamentos de Ifá. Nesse verso, o nome do babalaô baiano é utilizado para dizer que ele é responsável por “criar Ifá”, em seguida, surgem os nomes iorubas de seu Pai (Eliseu do Bonfim, Oyatogum) e de sua Mãe (Majebassã). Outro nome de Martiniano era conhecido era Ajimuda, em outro recado a composição vale-se de outras nominações para se referir a Martinano e Pai Adão (Adamassi), segundo Pai Paulo ambos eram muito amigos e Martiniano seria como um irmão mais velho de seu avô, Adão teria residido na casa da família de Martiniano em sua juventude, essa relação aparece nos recados abaixo.

RECADO DE IFÁ HOJE 20.09.2.013

Ojéalade criou Ifá para ter muitas vitórias;

Oyatogun, diz que para ter mais vitórias, tem que fazer oferendas, para ter mais forças para lutar contra os inimigos.

Majebansan, traz boas sortes nos ganhos de dinheiro,

lutar para fazer um bom casamento, com boas relações amorosas, e na velhice, os caminhos dos filhos, sejam de grandes relizações.

RECADO DE IFÁ HOJE o8.o7.2.014

Ésé

Ajimuda criou Ifá para Adamassi, verificar os motivos,

das relações variaveis;

Adamassi, falou que haviam dias com muitas tarturas;

Mas por diversas vezes, por diversos dias,

as farturas apareciam com dificuldades,

Foi quando Ifá pediu calma, que os odu hoje está vendo bem;

As graças estão vindo aos encontros da vida,

alcansando tudo o que desejar; 
Ainda mais, iniciando uma nova etapa na vida,, com as crianças, segurando a situação,por causa do amor e do filho, evitando separação do casal.

As boas sortes vem trazendo vitórias, no casamento, e não haverá perdas de dinheiro;

Terá alegrias de ter filhos, todos com boa saúde, bem realizados, com muitas tranquilidades e a paz que desejamos.

Os recados trazem também em sua narrativa, pessoas e lugares importantes do "passado" do nagô pernambucano. Certa vez, Pai Paulo me narrou sobre um culto à Oya (divindade dos raios), hoje esquecido, que era realizado em Recife e comandado por seu avô Adão. Os eguns daquela casa eram conhecidos como Ato e Aro. Eram ancestrais de duas mães de santo famosas em Pernambuco, Sinhá e Yaya, que comandavam um terreiro no centro da cidade, hoje desativado, próximo onde hoje localiza-se o Pátio do Terço. Como nesses dois recados:

RECADO DE IFÁ HOJE 15.08.2.013

Ato e Aro, foram que criaram Ifá para fazer união, para as pessoas receberem as graçar;

Sinhá e Yaýa, foram o ele desta desta irmandade, através de Abiké.

Adebaio Ydowu, foi encarregado de trazer as boas sortes,, com uma vida longa vida, com uma situação financeira rentável, com saúde e muita paz.

RECADO DE IFÁ HOJE 09.08.2.014

Ésé Itan Ifá

Ogun Biyi, criou Ifá Jibirilo, saber o que aconteceu, com a casa de Oyá, Jibirilo, através das consultas, soube de Ifá, que com o falecimento de Babá Adan, a referida casa, foi desativada, por não ter pessoas competentes para assumi-la. 
Ifá não está vendo bem.por não haver naquela época, para seguir ,

Na leitura dos versos de Ifá, é sempre recorrente uma menção ao tempo sobre o qual fala o verso, uma espécie de momento de bonanças, quando a pessoa, após os sacrifícios, alcançaria a estabilidade e harmonia que tanto deseja. Meu primeiro impulso foi tomar esse tempo com o que experimentava Pai Paulo em sua idade. Pai Paulo se aposentou como gerente do Banco Itaú, o que proporcionou para ele uma condição de vida com relativa estabilidade financeira. Imaginei que o tempo sobre o qual falam os versos era o tempo vivido por Pai Paulo nessa fase de sua vida, tratandose de um tipo de alegoria para que se as pessoas seguissem o que determina o jogo, tivessem as recompensas tal qual ele experimentara. Contudo, ao insinuar essa interpretação para Pai Paulo, ele a rejeitou (como habitual), dizendo que eu "não tinha entendido nada":

“Cada odu tem seu tempo, sua idade, às vezes, uma pessoa de trinta anos já é 'velha' em um odu, em outros com mais idade, essa velhice não tem a ver com tempo de vida não. Hoje em dia, as pessoas falam que a expectativa de vida aumentou, que besteira! Um ano hoje vale sete meses do de antigamente. Eu vejo os anos passarem como se fossem semanas de antes. A mim, essas notícias não enganam, minha mãe era pequenininha [faz um gesto com a mão sinalizando a altura], eu não nasci desse tamanho! A cultura, hoje em dia, é como rabo de cavalo, cresce para trás... Antigamente os orixás não gostavam de fotografia, meu avô mesmo nunca gostou, hoje em dia os santos fazem pose para mostrar o sapato...”

Os odus possuem seu tempo - o tempo interno a eles, que apresenta uma duração das etapas da vida em diferentes velocidades. Quando se é jovem em um, pode-se ser velho em outro. Um tempo de duração: os odus permanecem em tempos variáveis na pessoa e a pessoa permanece em tempos variáveis no caminho do odu - são temporalidades diferentes. Por isso, quando se joga hoje e sai um odu, em uma próxima consulta, aquele odu pode ter partido e estar sobre os domínios de outro. Contudo, há a duração do odu que acompanha uma pessoa ao longo de sua vida, que é o odu de nascimento.

Por meio da composição dos versos, Pai Paulo opera uma reversão entre as diferenças assimétricas do espaço e do tempo. Prescrever esse movimento como "memória" seria reduzi-lo em suas possibilidades. No caso de Pai Paulo, tudo se passa como se o tempo se movesse recursivamente aos eventos vividos pelas pessoas, de modo a coincidir com o tempo presente - se for possível imaginálo enquanto tempo presente.

O "impersonador" do verso diz sobre o "agora”, eles criam, em certo sentido, o "espaço" e o “tempo” por meio do movimento de Ifá. Algo análogo ocorreria com o Ifá cubano: 
Este tipo de relato, que existe literalmente aos milhares, ilustra dois temas formais que dialogam diretamente com o papel do que poderíamos chamar de "transcendência" na mitologia de Ifá. Em primeiro lugar, a linguagem ostensivamente histórica em que o relato é contado, como uma história de acontecimentos que tiveram lugar em um passado distante, em determinadas localidades africanas e lugares, colocam tais mitos em uma posição transcendente em relaçao a um estado atual de situaçoes que eles pretendem iluminar - nesse caso a construçao e uso do ókuele. De fato, como o estilo conto de fadas da estoria indicaria, o passado da "África", neste contexto, pode ser entendido como tendo existido, não só em uma distância quantitativa no tempo e no espaço, mas também em uma distância qualitativa: a "África" em tais relatos míticos acaba por adquirir a luminosidade de mitopoiese, assumindo o papel do que Viveiros de Castro chamou, com referência ao mito ameríndio, de 'passado absoluto' (2007, p. 157), que 'nunca esteve presente, e, portanto, nunca passa ' (HOLBRAAD, 2013, p. 115, tradução minha)

O que Pai Paulo ensina através da escrita de seus odus é que o jogo, apesar de obedecer a uma convencionalização da combinação entre as caídas dos ikins e o significado dos odus, impele que cada pessoa, ao aprender o manejo dos odus, tenha que compor, em relação com sua própria experiência, os enunciados de Ifá. Estes assumem contornos de registros autobiográficos, uma vez que a própria experiência de quem o executa é inserida, obrigatoriamente, na leitura de seus veredictos. O jogo não é uma fala de si - do "olhador" para o consulente -, mas um diálogo entre eles, entre o jogo e seu oficiante, entre ele e sua trajetória, da memória de si com os seus antepassados, seres, pessoas e lugares, os caminhos que levaram uma pessoa a aprender o jogo.

Como vimos, os versos são criados em um modo de dispor relações que ele relata, contendo: i) o odu transformado no nome do "impersonador" (ao transcrever o verso na internet, a combinação do odu é omitida, mantendo-se apenas o nome do criador daquele odu no verso); ii) a motivação daquele verso, ou seja, qual mensagem que ele transmite; iii) o recado do verso, escrito em diálogo com o "jogo de odibo" para transmitir quais ações devem ser executadas e para quem se destina o verso. 
É interessante notar que o verso escrito na internet é um recado coletivo. Por isso, é preciso “individuá-lo”, para dizer o que aquele verso específico diz para cada pessoa, ao entrar em relação com ela. Ou seja, tem-se um modo de diferenciação consciente contra um fundo de possíveis similaridades que a coletividade instaura. Segundo o modelo proposto por Pai Paulo, quando uma pessoa o procura, a partir do recado da internet, é preciso ver o que aquele recado específico diz para ela, isto é, é preciso tornar o recado particular, de modo a especificá-lo em uma pessoa, a partir da extensão do contexto coletivo, que também é, concomitantemente, transformado.

Nas etnografias sobre Ifá, é recorrente a atenção dada pelos pesquisadores ao papel dos versos de Ifá na constituição dos odus. Esses versos seriam interpretados como "arquétipos" ou modelos característicos da composição dos versos. ${ }^{13}$

Ao invés de interpretar tais características como "regras" ou "tipos”, entendo os versos de Ifá como um movimento de metaforização e que, por isso, não atuam enquanto "modelos". Não se trata de um "tipo" a ser referido na relação obtida entre o "personificador" do verso e seu contexto dos recados, tampouco de uma “classificação” daquilo que é narrado e sua posterior interpretação pela pessoa que narra a história para um terceiro componente. Poderíamos, em vez disso, situar essas ações como dimensões distintas - mas complementares - que convergiriam por meio do novo contexto ativado pela narrativa. Criando, então, uma composição entre o recado do jogo, as negociações entre o jogador e Ifá, e as correlações feitas pelo cliente.

O papel da "impersonação" em Ifá, contida nos versos, seria esse novo referente. Essa personificação obvia seu significado, como descrito por Wagner, através e por meio das analogias suscitadas pelos conteúdos dos versos: os criadores de Ifá, no casos dos versos de Pai Paulo, os orixás que "falam" nos recados do jogo de búzios e ainda quem o jogo "personifica”, além do ser (orixás, ancestrais, pessoas) "personificado" por ele.

Pai Paulo seria também um “personificador”, obteria, por meio da interpretação dos recados de Ifá, a força de sua “intuição"- recorrendo novamente a Wagner- por meio de capacidades "externas" que essa "personificação" acrescentaria a ele, fazendo coincidir, de modo análogo, o decurso de suas experiências e as situações ocorridas com o outro ser, um modo de reversão. Por meio das extensões elicitadas por Ifá, o babalaô também assumiria a capacidade de transformar essas novas situações, mediante os atos que esses recados determinam, agregando a capacidade transformadora do Ifá à sua. A resposta do jogo à indagação do cliente pode ser entendida como um ato de diferenciação (e individuação) contra o fundo mais generalista (de indiferenciação) dos vaticínios de Ifá.

\footnotetext{
${ }^{13}$ Sobre isso ver, na Nigéria: ABIMBOLA(1976); em Cuba: HOLBRAAD (2013)
} 
Nesse sentido, mais do que corresponder, o que o conceito de bater nos diz sobre o recado coincidir com a situação do cliente é que isso só é possível por meio da intuição, essa capacidade inata (e motivadora) de "saber ganhar do oculto", nas palavras de Pai Paulo. Algo similar pode ser visto naquilo que Javier- babalawo cubano e interlocutor de Holbraad- em uma instigante teorização, nomeou de metamorfose:

Você precisa saber como falar — para ser um orador de Ifá - para operar a 'metamorfose', como dizemos. [...] Você poderia vir até mim e a partir de uma história eu lhe dizer três coisas. Mas se você for até outra pessoa, ela poderia lhe dizer dez coisas, porque sabe como tirar o máximo proveito do oddu (sacarle provecho) (HOLBRAAD, 2004, p. 54, tradução minha).

Como vimos, os versos e odus serviriam como "exemplos" para as pessoas, e as pessoas serviriam como "exemplos" para os versos dos odus. Insisto nesse tipo de reversão, mais do que modelos ou quadros que fixariam a vida das pessoas, os odus apontam para essa relação, os recados de Ifá oferecem uma fundo para a figuração das vidas das pessoas, e essas reversamente oferecem uma nova figura para os recados de Ifá, como procurei demonstrar na composição dos recados, em especial, para papel dos personificadores dos versos.

\section{Algumas considerações}

Busquei compor um texto a partir das narrativas de Pai Paulo sobre a sua relação com Ifá (o que obviamente envolvia outras relações com outros seres). O que Pai Paulo nos ensina sobre Ifá é que o jogo, apesar de obedecer a certos princípios de combinação entre as caídas dos odus e o seus significados, também incorpora a própria experiência de quem o executa. O conhecimento sobre os odus é antes de tudo uma experimentação. Isso impele que cada pessoa, ao aprender o manejo dos odus, deve compor, com sua própria experiência, os enunciados de Ifá.

Os odus e os versos de Ifá, mais do que meios de comunicação ou sistemas de classificação, são como fenômenos da experiência que guiam e estabelecem modos de interação com o mundo, a partir de certas diposições do universo conceitual que os precipitam. Mas como esses jogos interagem entre si durante os rituais e a vida dos praticantes do nagô, no ato do jogo, essas diferentes modalidades servem como um contexto implícito, de uma para outra, uma relação/ reversão de figura e fundo.

No decorrer do trabalho, procurei explicar como esse modo de relação / reversão entre os odus e as modalidades dos jogos de búzios podem operar de maneira análoga em outros contextos. Chamei atenção, também, para como os aspectos cosmológicos de estruturação dos odus incidem no modo 
como eles são escritos nos cadernos dos praticantes do nagô, durante a aprendizagem do jogo e que, embora compartilhados, esses cadernos só “funcionariam” para aqueles que o escrevem, já que a eficácia do jogo, além do domínio técnico de sua execução, é motivada também pela intuição, uma habilidade que não pode ser ensinada, apenas herdada.

Procurei estender essas analogias para a composição dos "Recados de Ifá”, precipitada pela objetivação de uma nova modalidade de jogo, o "Jogo de Ifá com ikins, opom e opelê". Essa "nova" modalidade recuperada por Pai Paulo foi motivada pela sua leitura de um livro sobre Ifá, que serviu como gatilho para a atualização de uma prática que teria desaparecido de Recife em meados da década de 30 do século passado.

Essa experiência foi motiva por um evento dramático na vida de Pai Paulo, um AVC. Foi a doença que motivou um processo de cura por meio da leitura. Essa leitura, por sua vez, foi o que motivou sua atualização do jogo de Ifá. Porém isso não foi tudo. Para empreender essa atualização, Pai Paulo precisou "reconstruir" o sistema de Ifá por meio da composição dos versos de Ifá contidos no odu que o livro não retratava. Entretanto, "reconstruir" não seria o termo mais preciso para descrever essa atualização. Era preciso recuperar o jogo de Ifá, uma vez que esse jogo já esteve presente na história de sua família, de certo modo, com uma participação latente.

A atualização do jogo de Ifá por Pai Paulo, na forma dos versos que ele elabora, apresenta modos de criação que não passam por uma criação ex nihilo. Essa atualização dispõe e expressa diferentes composições e arranjos de relações com “aquilo que já existia no tempo de meu avô", em certo sentido, com aquilo que já era ‘dado'. Dessa forma, Pai Paulo não se vê como um “criador”, como me disse certa vez, "sou um improvisador".

Como dito acima, a atualização do jogo de Ifá, na visão de Pai Paulo, vem de sua "herança espiritual" e está vinculada a uma concepção muito particular de consanguinidade. Essa consanguinidade pode ser entendida como um fundo de preexistência diante da qual a criação emergiria como figura. Além disso, Pai Paulo diz que não poderia ficar apenas na "leitura" do livro ou de cadernos - mesmo que estes contivessem todos os odus e seus recados. O jogo, para "funcionar", obriga que a pessoa componha ela mesma seus enunciados, a partir de sua experiência e intuição, o que implica que ele não poderia ser ensinado, mas somente transmitido ao longo da vida de um “iniciado” no candomblé. Essa transmissão seria mediada também pelas "heranças”, um tipo de “dom"14.

${ }^{14}$ Essa é uma discussão que tem chamado a atenção de diversos antropólogos/as na etnologia afro-brasileira. Espero, em um outro momento, contribuir para esse debate, a partir do meu material etnográfico sobre a relação entre dom e iniciação (cf. Boyer, 1996; Halloy, 2010; Goldman, 2012; Sansi, 2009, entre outros). Dessa discussão, tenho como horizonte a proposição de 
Essa atualização ou reificação, em outro termo de Pai Paulo, consiste na escrita dos "versos de Ifá" que teriam se perdido com o desaparecimento do jogo, seriam motivados por aquilo que José Jorge de Carvalho(1987) nomeou como "Força da nostalgia", essa força me parece apontar para a diferenciação constantemente em jogo nessa "recuperação".

Esses versos são “composições” que Pai Paulo elabora a partir das respostas de Ifá a uma sequência específica de perguntas; desse diálogo, ele elabora o recado, relacionando ancestrais, orixás, eventos e lugares. Segundo o modelo proposto por Pai Paulo, quando uma pessoa o procura, a partir do recado da internet, é preciso ver o que aquele recado específico diz para ela, isto é, é preciso tornar o recado particular, de modo a especificá-lo para uma pessoa de acordo com a extensão do contexto coletivo que, concomitantemente, é transformado.

Os recados de Ifá, implicam ainda em certa externalização dos conhecimentos de Pai Paulo (e de Ifá) em sua capacidade de escrever os versos de acordo com suas heranças espirituais e intuições. O objetivo dessa escrita é fazer com que Pai Paulo revele aos seus descendentes (e os que visitam sua página virtual) aquilo que diz Ifá em seus vaticínios e impedir que, ao morrer, esses conhecimentos novamente se percam - por isso ele se refere, logo no início de seu projeto, ao desejo de ser um "ancestral do futuro", a escrita dos recados passa por esse desejo. Esses recados virtuais possibilitam a solução dos problemas mediante a realização de uma obrigação, uma oferenda.

Essa atualização de Ifá busca recuperar essas perdas anteriores. Difundir esse conhecimento a um público maior é uma ampliação dos efeitos dos recados de Ifá em uma nova escala. A atualização de Ifá, mais do que o resgate de elementos "originais" recuperados de um passado, compõe-se de experimentações e, principalmente, de modos de reversão, o que motiva sempre uma diferenciação relativa ao que foi "perdido" no passado e retorna agora pela ação de Pai Paulo. Ao "retificar" ou "atualizar" esse conhecimento, Pai Paulo se singulariza frente seus ancestrais, esse movimento que motiva e potencializa os efeitos de sua criatividade em outros contextos, como, por exemplo: ampliação do repertório de cantigas do nagô, novas invocações, entre outras.

Essa motivação contida na atualização de Ifá se estende a outros projetos, como a introdução de novos cânticos, intensificação de rituais antigos, entre outros. Ao mesmo tempo em que tais ações diferenciam Pai Paulo daquilo que estava "dado" com a morte de seu pai e tio, tais empreendimentos são uma oportunidade para Pai Paulo fazer as coisas ao modo como eram feitas no tempo de seus 
ancestrais, eles se situam como um fundo do qual parte Pai Paulo para "improvisar" e assim reverter seu pessimismo sobre o desaparecimento de tais práticas.

\section{Bibliografia consultada}

ABIMBOLA, Wande. Ifa: An exposition of Ifa literary corpus. Athelia Henrietta Press. 1997.

APTER, Andrew. Black critics and kings: the hermeneutics of power in Yoruba Society. Chicago, London: The University of Chicago Press, 1992.

AYOH'OMIDIRE, Félix. Yorubanidade Mundializada: O reinado da oralitura em textos yorubánigerianos e afro-baianos contemporâneos. Tese (Doutorado) - Universidade Federal da Bahia, 2006. BANAGGIA, Gabriel. Inovações e controvérsias na antropologia das religiões afro-brasileiras. Dissertação (Mestrado) - Antropologia Social, PPGAS/Museu Nacional/Universidade Federal do Rio de Janeiro, Rio de Janeiro, 2008.

. As forças do jarê: movimento e criatividade na religião de matriz africana da Chapada Diamantina. Rio de Janeiro: UFRJ/MN, 2013.

BARBER, Karin. Como o homem cria deus na África ocidental: atitudes dos Yorubá para com o òrìsàe, In: MOURA, Carlos Eugênio Marcondes (org.). Meu sinal está em teu corpo. São Paulo: EDICON/EDUSP, 1989 .

BASCOM, William Russell. Ifa divination: communication between gods and men in West Africa. Indiana University Press, 1969.

Sixteen cowries: Yoruba divination from Africa to the New World. Indiana

University Press, 1993.

BASTIDE, Roger. "Contribuição ao estudo do sincretismo católico-fetichista." Sociologia do folclore brasileiro: p. 106-133. 1973.

Le principe d'individuation: contribution à une philosophie africaine ${ }^{e e}$ In La notion de personne en Afrique Noire. Paris: Éditions CNRS, p. 33-43. 1973 b.

. Estudos afro-brasileiros. São Paulo: Perspectiva, 1983.

O candomblé da Bahia: rito nagô. São Paulo: Companhia das Letras, 2001 (1958).

BASTIDE, Roger ; VERGER, Pierre. Contribuição ao estudo da adivinhação em Salvador (Bahia). In: MOURA, Carlos Eugênio Marcondes de (org.). Olóòrisà: escritos sobre a religião dos orixás. São Paulo: Ágora, 2003 [1953]. p. 57-85.

BOYER, Véronique. Le don et l'initiation: de l'impact de la littérature sur les cultes de possession au Brésil. 1996. 
BRAGA, Júlio Santana. O jogo de búzios. Editora Brasiliense, 1988.

CARVALHO, José Jorge. Ritual and music of the sango cults of Recife, Brazil. Doctoral dissertation, Queen's University, 1984.

A força da nostalgia: a concepção de tempo histórico dos cultos afrobrasileiros tradicionais. Religião e Sociedade, 14, (2), p. 36-61. 1987.

Cantos sagrados do xangô do Recife. Fundação Cultural Palmares, 1993.

CASTILLO, Lisa Earl. Entre a oralidade e a escrita: a etnografia nos candomblés da Bahia.

Edufba, 2008.

COSTA, Ivan Horácio. Ifá: o orixá do destino: o jogo de Ôpón e do ôpêlê Ifá. 1995.

GOLDMAN, Marcio. Formas do saber e modos do ser: observações sobre multiplicidade e ontologia no candomblé. Religião e Sociedade, 25 (2), p. 102-120. 2005.

. Como funciona a democracia: uma teoria etnográfica da política. Rio de Janeiro: 7 Letras, 2006.

- Histórias, devires e fetiches das religiões afro-brasileiras: ensaio de simetrização antropológica. Análise Social, v. XLIV, n. 190, p. 105-137. 2009.

. O fim da antropologia. Novos Estudos CEBRAP, v. 89, p. 195-211. 2011.

. "Cavalo dos deuses: Roger Bastide e as transformações das religiões de

matriz africana no Brasil." Revista de Antropologia 54.1. 2012a.

O dom e a iniciação revisitados: o dado e o feito em religiões de matriz africana no Brasil. Mana, v. 18, n. 2, p. 269-288. 2012 b.

HALLOY, Arnaud. Dans l'intimité des orixás. Corps, rituel et apprentissage religieux dans une famille-de-saint de Recife, Brésil. Thèse de Doctorat, ULB-Bruxelles / EHESS-Paris, 2005.

. Chez nous, le sang règne! Terrain, n. 2, p. 40-53. $2010 a$.

.La consultation par Ifa à Recife: La (re)naissance de une tradition ? Cahiers du Brésil Contemporain 75/76, p. 57-89. 2010b.

HOLBRAAD, Martin. Estimando a necessidade: os oráculos de Ifá e a verdade em Havana. Mana, 9 (2), p. 39-77. 2003

. Truth in motion: the recursive anthropology of Cuban divination.

University of Chicago Press, 2012.

LUCIEN, Lévy-Bruhl. Les fonctions mentales dans les sociétés inférieures. Paris, Alcan, 1910.

MOL, Annemarie. Política ontológica: algumas ideias e várias perguntas. Objectos impuros:

Experiências em estudos sociais da ciência. Ed. Afrontamento, 2008. 
MOTTA, Roberto. Meat and feast: the xango religion of Recife, Brazil. Diss. Columbia University, 1988.

Le Sacrifice Xangô à Recife. Social compass, v. 50, n. 2, p. 229-246, 2003.

OPIPARI, Carmen. O candomblé, imagens em movimento: São Paulo, Brasil. Editora da Universidade de São Paulo.2010

PINTO FILHO, Olavo de Souza. Cadernos nagô. A antropologia reversa do Alapini Paulo Braz Ifamuide. 2015. Dissertação (Mestrado em Antropologia Social) - Faculdade de Filosofia, Letras e Ciências Humanas, University of São Paulo, São Paulo, 2015. Disponível em: <http://www.teses.usp.br/teses/disponiveis/8/8134/tde-16062015-124158/>. Acesso em: 2015-11-05.

RABELO, Miriam. Enredos, Feituras e Modos de Cuidado: dimensões da vida e da convivência no candomblé. 1. ed. Salvador: EDUFBA, v. 1. 294p. 2014.

RIBEIRO, René. Cultos afro-brasileiros do Recife. Recife: Instituto Joaquim Nabuco, 1978 (1952). Antropologia da religião e outros ensaios. Recife: Massangana, 1982 (1955).

SANSI-ROCA, Roger. "Fazer o santo": dom, iniciação e historicidade nas religiões afrobrasileiras. Análise Social, (190), 139-160. 1982 (1955).

SANTOS, Juana Elbein dos. Os Nàgô e a morte: pàde, àsèsè e o culto Égun na Bahia. Petrópolis: Vozes, 2002.

SEGATO, Rita Laura. A folk theory of personality types: Gods and their symbolic representation by members of the Sango cult in Recife, Brazil. 1984. Tese (Doutorado) - Queen's University, 1984.

Inventando a natureza: família, sexo, gênero no xangô do Recife. In:

MOURA, Carlos Eugênio Marcondes de (org.). Candomblé: religião do corpo e da alma - tipos psicológicos nas religiões afro-brasileiras. Rio de Janeiro: Pallas, 2004. p. 45-102.

Santos e daimones. $O$ politeísmo afro-brasileiro e a tradição arquetipal.

Brasília: EdUnB, 2005[1995].

SERRA, Ordep J. Trindade. Águas do Rei. Petrópolis: Vozes, 2001.

.No caminho de Aruanda: a umbanda candanga revisitada. Afro-Ásia

(2526), p. 215-256. 1995.

SILVA, Vagner Gonçalves da. Orixás da metrópole. Petrópolis: Vozes, 1995.

VERGER, Pierre. Contribuição ao estudo da advinhação em Salvador. Revista do Museu Paulista, 7, p. 357-380. 1981(1953).

. Orixás: deuses iorubás na África e no Novo Mundo. São Paulo: Corrupio. 1994.

VERGER, Pierre e BASTIDE, Roger. Dimensões de uma amizade. Rio de Janeiro: Bertrand, 2002. 
WAGNER, Roy. "The Innovation of Meaning in Daribi Religion." Chicago: University of Chicago Press, 1972.

A invenção das Culturas. São Paulo: Cosac Naify, [1975] $2010 a$. 